\title{
The pond biodiversity index "IBEM": a new tool for the rapid assessment of biodiversity in ponds from Switzerland. Part 2. Method description and examples of application
}

\author{
Nicola Indermuehle, Sandrine Angélibert, Véronique Rosset \& Beat Oertli* \\ hepia Geneva, University of Applied Sciences Western Switzerland, technology, architecture and landscape. \\ CH-1254 Jussy-Geneva, Switzerland.
}

*Corresponding author: beat.oertli@ hesge.ch

Received: 12/12/08

Accepted: $30 / 6 / 09$

\begin{abstract}
The pond biodiversity index "IBEM": a new tool for the rapid assessment of biodiversity in ponds from Switzerland. Part 2. Method description and examples of application

Ponds are now widely recognized to contribute significantly to regional freshwater biodiversity. Therefore, tools to easily and rapidly assess biological quality specifically for these aquatic habitats have been increasingly requested by conservation planners and nature managers. In close association with practitioners, we developed such a method for Switzerland; the pond biodiversity index "IBEM". The IBEM-Index is based on the assessment of the taxonomic richness of 5 groups: aquatic vegetation, Gastropoda, Coleoptera, adult Odonata and Amphibia. No abundance data are necessary and genus level identification is required for all groups except Amphibia (species level). The sampling methodology is a stratified random strategy and allows the use of richness estimators to transform the observed taxonomic richness $\left(S_{\text {obs }}\right)$ into true taxonomic richness $\left(S_{\text {true }}\right)$. As the IBEM assessment follows the methodology presented in the Water Framework Directive, it is based on the calculation of the ratio of true taxonomic richness $\left(S_{\text {true }}\right)$ to reference-based predicted richness $\left(S_{\text {ref }}\right)$. Each of the five taxonomic groups is assessed separately and the overall biological quality of any given pond (i.e. the IBEM-Index) is the average of the five ratios. This score is later converted into one of five quality classes for each pond: bad (0 to 0.2$)$, poor ( $>0.2$ to 0.4$)$, moderate $(>0.4$ to 0.6 ), $\operatorname{good}(>0.6$ to 0.8$)$, and high ( $>0.8$ to 1 ).

In this paper, the implementation of the IBEM-Index is described in detail. The sampling methodologies are developed (for the biodiversity and the environmental variables) as well as the assessment methodology. Finally, two examples are presented in detail, for a "good" quality pond and for a "bad" quality pond. The method implementation also includes a website (http://campus.hesge.ch/ibem) which allows the online calculation of the index, and provides support for both sampling and assessment methodologies to users.

The IBEM-Index is a rapid assessment method which gives an overall value of pond biodiversity in terms of taxa richness and can be used, for example, in regional screenings or site monitoring in Switzerland. Moreover, as biodiversity is generally recognized as a good indicator of global ecological quality, the IBEM-Index can also be used to investigate ecosystem quality.
\end{abstract}

Key words: Bioassessment, monitoring, small waterbodies, nature conservation, case study, practitioners, macroinvertebrates, aquatic plants, amphibians.

\section{RESUMEN}

Índice de biodiversidad de charcas "IBEM": una herramienta para la evaluación rápida de la biodiversidad de charcas en Suiza. Parte 2. Descripción del método y ejemplos de aplicación

Está ampliamente reconocido que las pequeñas masas de agua (charcas) contribuyen de forma significativa a la biodiversidad regional de las aguas dulces. Por tanto, las herramientas que de manera rápida y fácil evalúen específicamente la calidad biológica de estos hábitats acuáticos están siendo requeridas cada vez más por profesionales de la gestión y conservación del medio natural. En estrecha colaboración con estos profesionales, se ha desarrollado un método de este tipo para Suiza; el índice de biodiversidad de charcas "IBEM". El Índice-IBEM se basa en la evaluación de la riqueza taxonómica de 5 grupos: vegetación acuática, gasterópoda, coleópteros, odonatos (adultos) y anfibios. No son necesarios datos de abundancia y se requiere un nivel identificación de género para todos los grupos excepto para los anfibios (nivel de especie). Se usa un muestreo 
aleatorio estratificado que permite obtener estimadores para transformar la riqueza taxonómica observada $\left(\mathrm{S}_{\text {obs }}\right)$ en riqueza taxonómica real $\left(\mathrm{S}_{\text {true }}\right)$. La evaluación IBEM sigue la metodología de la Directiva Marco del Agua, que se basa en el cálculo de la relación entre la riqueza taxonómica real $\left(\mathrm{S}_{\text {true }}\right)$ y la riqueza esperable en un estado de referencia $\left(\mathrm{S}_{\text {ref }}\right)$. Cada uno de los cinco grupos taxonómicos se evalúa por separado y la calidad biológica de una charca determinada (Índice-IBEM) es la media de los cinco coeficientes. Este resultado es posteriormente asignado a una de las cinco clases de calidad: malo ( 0 a 0.2 ), deficiente (>0.2 a 0.4), moderado (>0.4 a 0.6), bueno (>0.6 to 0.8), y muy bueno (>0.8 a 1 ).

En este artículo, se describe detalladamente la aplicación del índice IBEM y se desarrollan las metodologías de muestreo (para la biodiversidad y las variables ambientales) y de valoración utilizadas. Por último, se presentan con detalle dos ejemplos, una charca con "buena" calidad y otra con "mala" calidad. Se incluye también una página web (http://campus.hesge.ch/ibem), que permite el cálculo del índice a través de internet y sirve de apoyo a los usuarios en las metodologías de muestreo y de valoración.

El índice IBEM es un método de evaluación rápida que da un valor general de la diversidad biológica de una charca en términos de riqueza de taxones y se puede utilizar, por ejemplo, a nivel regional o en el seguimiento de una localidad, en Suiza. Además, como la biodiversidad es un buen indicador de la calidad ecológica global, el índice IBEM también se puede usar para evaluar el estado del ecosistema.

Palabras clave: Indicadores biológicos, seguimiento, charcas, conservación de la naturaleza, casos de estudio, medioambientalistas, macroinvertebrados, plantas acuáticas, anfibios.

\section{INTRODUCTION}

Pond ecosystems contribute significantly to regional freshwater biodiversity (Nicolet et al. 2004, Oertli et al. 2004, Williams et al. 2004, Angelibert et al. 2006). In the last 15 years, this has consistently been shown in many parts of Europe. As a result, tools to easily and rapidly assess the biological quality of these aquatic habitats have been increasingly requested by conservation planners and nature managers.

Method have previously been developed (e.g. Biggs et al., 2000; Boix et al., 2005; Chovanec et al., 2005; Oertli et al., 2005; Menetrey et al., 2008; Solimini et al., 2008), but the characteristics of many of these (e.g. special type of ecosystems, restricted geographical use, high cost) prevent their use by practitioners from Switzerland. To address this, we developed such a method specifically for, and in association with Swiss practitioners: the pond biodiversity index "IBEM". Throughout the process, a selection of representative end users such as nature conservation managers, consultants, governmental organizations and taxonomic experts were consulted on the theoretical and practical aspect of the method in order to fulfill their requirements. The IBEM-Index is simple, stan- dardized, cheap, adjustable and consistent with the relevant legislative framework (Angélibert et al. 2009). The new method, IBEM, is based on the biodiversity of five taxonomic groups, four of which are identified at genus (aquatic plants, aquatic Gastropoda, aquatic Coleoptera, adult Odonata), and one at species level (Amphibia). The sampling methodology is a stratified random strategy. The assessment follows the methodology adopted by the European Water Framework Directive, and the ratio of the observed richness to a reference-based predicted richness is converted into one of five quality classes for each pond. The final index is the mean of the five assessment scores. To facilitate the method implementation, a website (http://campus.hesge.ch/ibem) enables the calculation of the index online, and provides support on both sampling and assessment methodologies to users. Full details of the development of IBEM have been presented in an another paper (part 1, see Angelibert et al., 2009). In this paper (part 2), we present the implementation of the IBEM-Index, including the sampling (for biodiversity and environmental variables) and assessment methodologies. Finally, two detailed examples are presented, one for a "good" quality pond and one for a "bad" quality pond. 


\section{RANGE OF APPLICATION (TYPE OF POND -GEOGRAPHICAL AREAS)}

The IBEM-Index can be used to assess ponds with a surface area of $50 \mathrm{~m}^{2}$ to $60000 \mathrm{~m}^{2}$, and a mean depth between $30 \mathrm{~cm}$ and $900 \mathrm{~cm}$.

The method is valid (i) in Switzerland and the close border regions of neighbour countries (i.e. with a $100 \mathrm{~km}$-wide belt), and (ii) for waterbodies situated in the colline or montane altitudinal belt (300-1000 m.a.s.l.). For other geographical regions (with different species pools), the sampling strategy can be adopted as it stands or easily adapted. However, a different reference system based on biological data or expert knowledge would have to be developed in order to predict the reference richness $\left(S_{\text {ref }}\right)$ used in the IBEM-Index assessment.

\section{METHOD FOR SAMPLING BIODIVERSITY AND MEASURING ENVIRONMENTAL VARIABLES}

The IBEM-Index for sampling biodiversity has been specifically adapted (see Angélibert et al., 2009) from the PLOCH assessment method (Oertli et al., 2005). The IBEM-Index is based on the assessment of the taxonomic richness of five groups: aquatic vegetation, Gastropoda, Coleoptera, adult Odonata and Amphibia. The choice of these indicator groups has been largely discussed by Oertli et al. (2005) and supported by further studies (Auderset Joye et al., 2004; Menetrey et al. 2005, 2008; see also Cordoba-Aguilar, 2008 for Odonata). For Odonata, the adult stage was selected because identification and sampling are easier and less expensive than for larvae or exuviae. Moreover, even though allochthonous taxa can generate background noise when recording an adult assemblage, this noise can be coped with because its magnitude does not prevent identification of the main trends (Oertli, 2008). Presence of adults is also a metric indicating the quality of the environment of a pond (shoreline, helophytic vegetation, buffer area) and has therefore to be considered.

No abundance data is required and taxa identification is to genus level for all groups except
Amphibia (species level). Exotic taxa are not taken into consideration to evaluate the biodiversity with the IBEM-Index as they are not representative of the autochtonous biodiversity of a pond. The IBEM-Index measures the "quality" (and not the functioning of the ecosystem) and cannot therefore include exotic species. The sampling methodology allows the use of richness estimators (Jackknife-1, Burnham \& Overton, 1979) to transform the observed taxonomic richness $\left(S_{\text {obs }}\right)$ into true taxonomic richness $\left(S_{\text {true }}\right)$. Finally, this true richness is compared to the reference richness $\left(S_{\text {ref }}\right)$ that would be expected for reference conditions.

\section{Aquatic vegetation}

Aquatic plants are sampled once in early July, with square plots $(0.5 \times 0.5 \mathrm{~m})$ equally distributed along transects which are regularly spaced perpendicular to the longest axis of the pond (see examples in Fig. 4). Areas deeper than $3 \mathrm{~m}$ are not sampled. The two square plots located at both ends of each transect must be placed directly against the shoreline, covering only the water (and not the shore). In case of fluctuating water level, shoreline square plots must be placed at the usual pond limit. The position of aquatic or terrestrial plants can help to locate this limit. For example, Mentha aquatica or Veronica beccabunga are usually located at the shoreline but with their stems reaching out of the water. If the pond has a dense reedbed or sedges that are impossible to penetrate, the square plots are located in front of this area, on the open water. The number of sample plots $(n)$ in relation to pond area is calculated as follows: $n=30-29.1 *$ $\log _{10}($ area $)+8.6 *\left(\log _{10}(\text { area })\right)^{2}$ (see part 1 , Angelibert et al. 2009). This number allows enough data to be gathered for each pond so that observed aquatic plant richness $\left(S_{\text {obs }}\right)$ reaches on average $70 \%$ of true richness $\left(S_{\text {true }}\right)$. In each plot, the presence or absence of aquatic plant genera is recorded, with the help a grapnel or an aquascope as necessary. The depth is recorded in each square plot, and is later used to calculate the mean pond depth (see environmental variables section). Only aquatic plants are recorded and these are defined 
as one of 254 species listed in the highest humidity class $(=5)$ by Landolt (1977). This includes true hydrophytes (species submerged or with floating leaves) and many emergent plants. To this 'aquatic' species pool were added 22 species listed by Landolt (1977) under humidity class 4: Juncus effusus, Carex canescens, Carex flava, Carex lepidocarpa, Carex nigra, Eleocharis acicularis, Eleocharis quinqueflora, Equisetum palustre, Galium palustre, Agrostis stolonifera, Juncus conglomeratus, Scirpus sylvaticus, Juncus filiformis, Juncus inflexus, Lysimachia nummularia, Lythrum salicaria, Lysimachia vulgaris, Mentha longifolia, Myosotis scorpioides, Ranunculus repens, Rorippa palustris, Juncus articulatus. The Characeae are considered as a single taxon. In the case of "mixed" genera which include both aquatic and non-aquatic species (such as Carex sp.), the genus is considered only if the observed specimen belongs to an aquatic species. Exotic species are not taken into account for the IBEM-Index (for example Elodea nuttallii). In both these instances, a specimen may require identification to species level to be either included or discarded in the results.

A table with aquatic genera and species taken into account in the IBEM-Index can be downloaded from the IBEM website (http://campus. hesge.ch/ibem/flore.asp).

\section{Gastropoda and Coleoptera}

Aquatic Gastropoda and aquatic Coleoptera (larvae and adults) are sampled once in early July, with a small-framed hand-net (rectangular frame $14 \times 10 \mathrm{~cm}$, mesh size $0.5 \mathrm{~mm}$ ). This sampling date was chosen as the best compromise between acceptable cost of the method and satisfactory results. Indeed, the sampling of aquatic invertebrates can be coupled with the sampling of aquatic vegetation. Gastropoda and Coleoptera are present in the pond all along the year (with the exception of a few Coleoptera families). Furthermore, both adults and larvae of Coleoptera are sampled, increasing the chance to sample the Coleoptera taxa. The number of required samples $(n)$ in relation to pond area is calculated as follows: $n=15.5-10.5 * \log _{10}($ area $)+$
$2.7 *\left(\log _{10}(\text { area })\right)^{2}$ (see part 1, Angelibert et al. 2009). This number allows enough data to be gathered for each pond so that observed richness $\left(S_{\text {obs }}\right)$ reaches on average $90 \%$ of true Gastropoda richness $\left(S_{\text {true }}\right)$ and $70 \%$ of true Coleoptera richness $\left(S_{\text {true }}\right)$. Sampling is stratified across the dominant mesohabitats. Sediments and algae (except Characeae) are not sampled because of their low taxonomic richness for the selected taxa. Mesohabitats are divided into two main categories: (i) shoreline aquatic mesohabitats, and (ii) those occurring between the shoreline (excluding the shoreline itself) to a depth of $2 \mathrm{~m}$ (deeper zones are not sampled). Only mesohabitats covering more than $1 \%$ of the total mesohabitat area are taken into account and only the pond area comprising the mesohabitats listed in Table 1 is considered (this list is also available on the IBEM website, http://campus. hesge.ch/ibem/coleopteres.asp). Two thirds of the samples are then allocated to the first mesohabitat category and the remaining samples are allocated to the second. The samples are distributed between the mesohabitats in proportion to the coverage of each, with a minimum of one sample per mesohabitat. One unit sample consists of the intensive sweeping of the net through the habitat for 30 seconds. If one mesohabitat is composed of scattered patches, the sampling time $(30 \mathrm{~s})$ is divided into shorter periods and distributed between patches (= one composite sample). If the number of mesohabitats is larger than the number of samples, the surveyor groups together the mesohabitats situated in the lowest position in Table 1 (for example: group together mesohabitats 3.2.1. and 3.1. (Table 1)) and then samples each habitat for $15 \mathrm{~s}$ (= one composite sample). If there is one sample to distribute and two habitats have the same coverage, the user has to choose the habitat listed in the highest position in Table 1 (for example: hydrophytes (1) are preferred to Helophytes (2); submerged plants (1.1.) are preferred to floating leaves (1.2.); etc).

Finally, Gastropoda and Coleoptera are sorted in the field and presence/absence of genera in each sample is recorded in the laboratory. Empty shells of Gastropoda are not sorted. For inexperienced staff, additional sorting in the la- 
Table 1. List of the mesohabitats taken into account for the IBEM-Index sampling method. Two thirds of the samples are allocated to the habitats occurring at the shoreline (land-water interface) (A); one third of the samples are allocated to the habitats occurring between the shoreline and a depth of $2 \mathrm{~m}$ (B). Lista de los mesohabitats considerados en el método de muestreo del índice IBEM. Dos terceras partes de las muestras se obtienen en hábitats situados en las orillas (interfaz tierra-agua) (A); un tercio de las muestras se obtiene en hábitats entre la orilla y una profundidad de $2 \mathrm{~m}(\mathrm{~B})$.

Mesohabitats

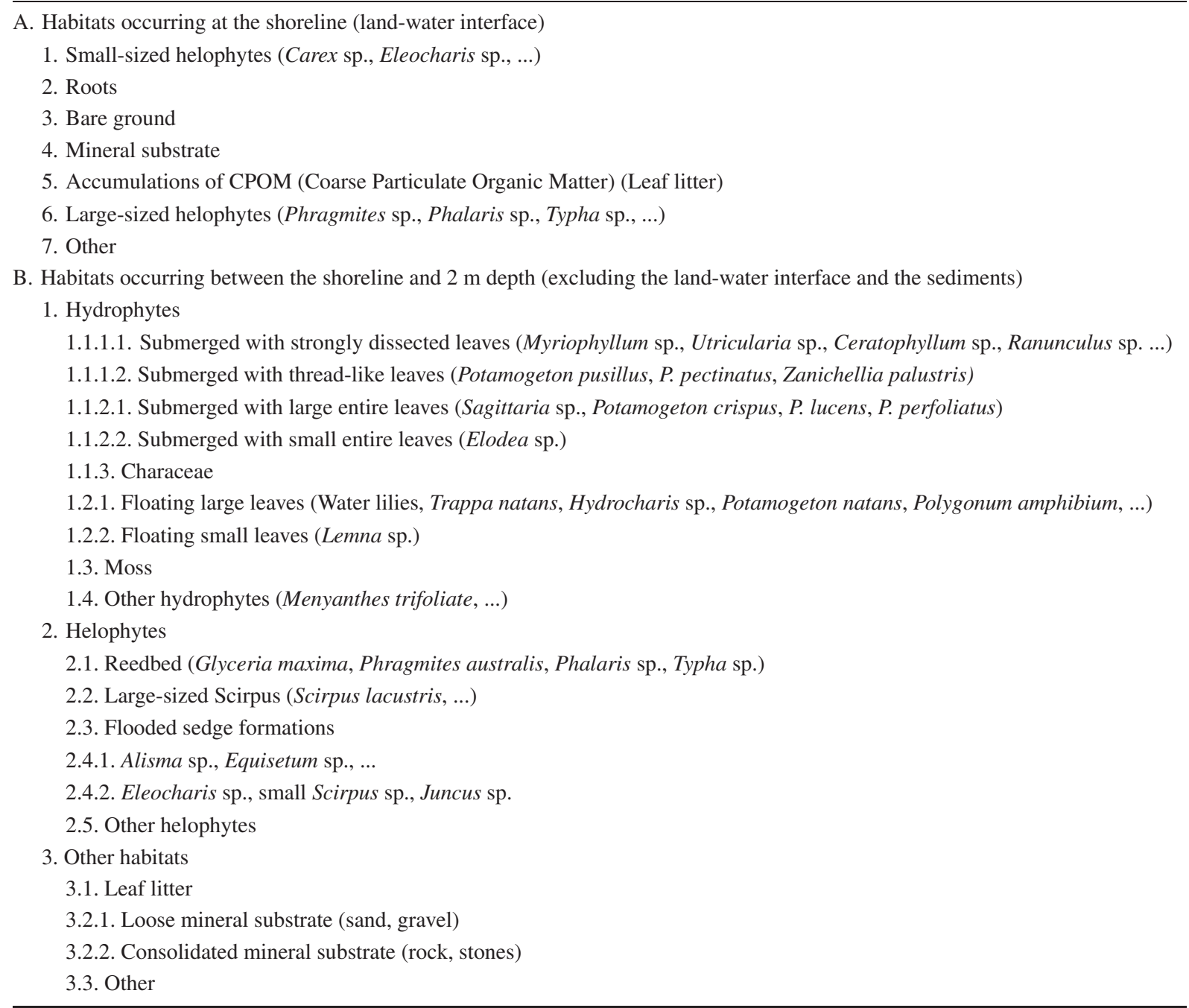

boratory is recommended. Identification can be made either in the field or in the lab on preserved material. Exotic species are not taken into account for the IBEM-Index; consequently it can be necessary to identify the species of a given specimen in order to discard an exotic taxon (for example Gyraulus parvus). The list of Gastropoda and Coleoptera genera used for the IBEM-Index is available on the IBEM website (http://campus.hesge.ch/ibem/coleopteres.asp).

\section{Odonata}

Adult Odonata are sampled twice; at the end of spring and in mid-summer (Fig. 1). The sampling dates depend on the altitude of the studied pond. Observations are made in plots $(10 \mathrm{~m} \times 30 \mathrm{~m})$ distributed along one third of the shore length, including all the occurring habitats (Fig. 2).

At least 3 plots must be distributed along the shoreline (i.e. ponds with a shoreline length 
altitude $(\mathrm{m})$

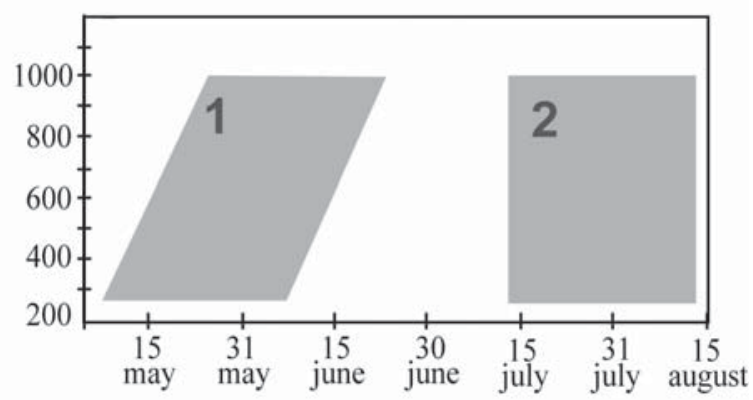

Figure 1. Late-spring (1) and mid-summer (2) sampling periods for adult Odonata in relation to altitude. These periods were identified by means of phenological data on adult Odonata provided by the Swiss Biological Records Centre (number of observations per species, pooled in function of altitude and date). Periodos de muestreo para los odonatos adultos en relación con la altitud: final de primavera (1) y mediados de verano (2). Estos periodos se han determinado mediante datos fenológicos de odonatos adultos facilitados por el Swiss Biological Records Centre (número de observaciones por especie, agrupados en función de la altitud y fecha).

$<270 \mathrm{~m}$ are sampled along more than a third of the shoreline). Each plot is sampled for 10 minu- tes. Sampling day conditions are: (i) air temperature between $20^{\circ}$ and $30^{\circ} \mathrm{C}$ (approximately between $11 \mathrm{~h} 30$ and 16h00), (ii) sunshine and (iii) no wind. Presence of Odonata genera is recorded in each plot using binoculars. If identification is not possible with binoculars, Odonata can be captured using a butterfly net. Strictly lotic taxa, such as Calopteryx and Cordulegaster, are not recorded. The list of Odonata genera used for the IBEM-Index is available on the IBEM website (http://campus.hesge.ch/ibem/odonates.asp).

\section{Amphibia}

The field protocol follows the method by Schmidt (2004), used for the red list update in Switzerland. Presence of amphibian species is recorded during four visits (March, April, May and June). Each visit lasts 1 hour. The first visit is made during the night, the other three at dusk. Standardised sampling conditions are mild nights,

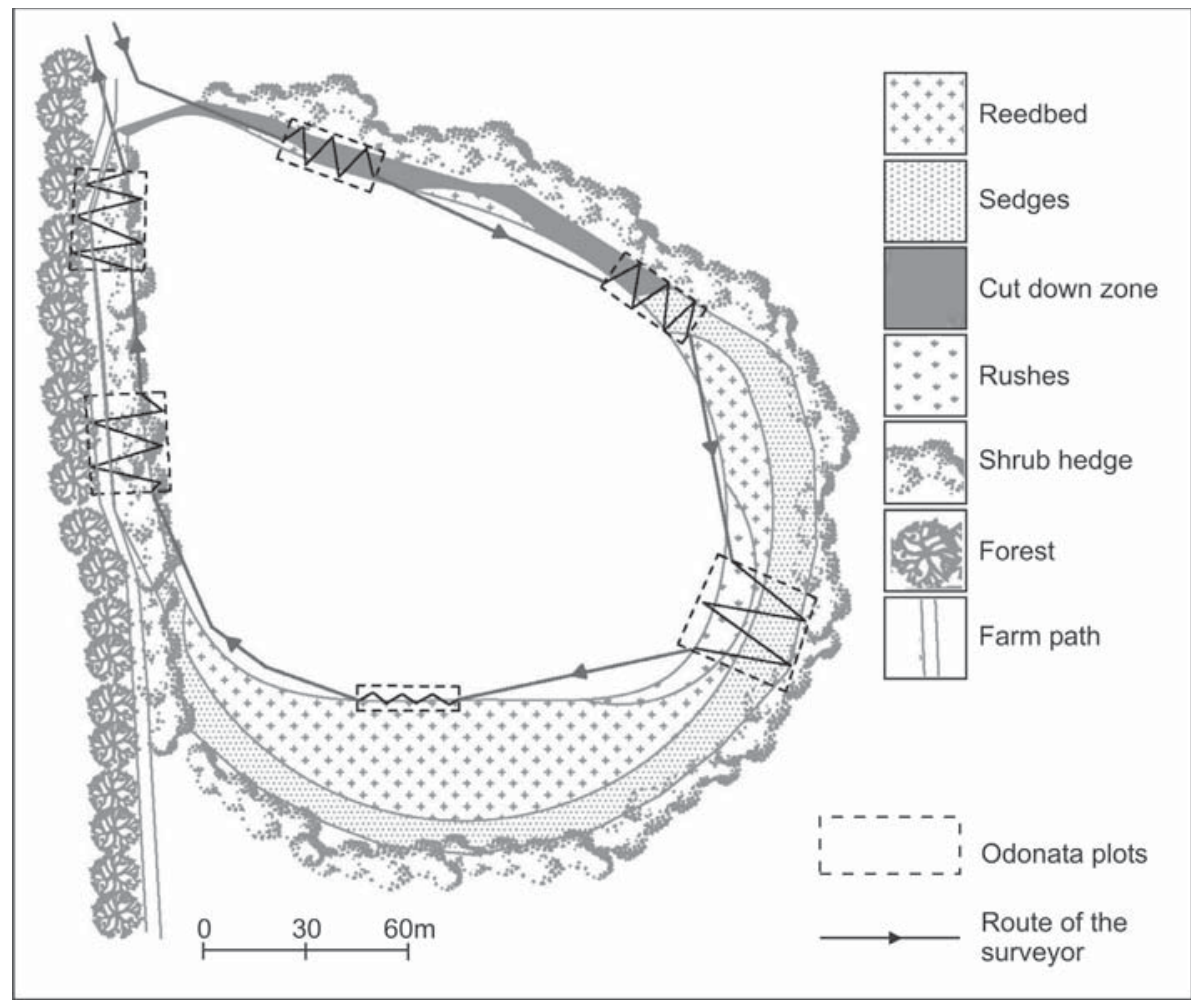

Figure 2. Example of distribution of Odonata plots around a pond with route used by the surveyor. Ejemplo de distribución de las bandas de muestreo de odonatos en torno a una charca, con la ruta utilizada por el observador. 
with no wind or rain. Sampling after a long period of drought must be avoided. The amphibians (adults, subadults, larvae) are surveyed by means of (i) search by flashlight, (ii) identification of calls, and (iii) dip netting. The two species Rana esculenta and $R$. lessonae are considered as one single taxon (green frog complex). The taxonomic reference list, used for the IBEMIndex, is available on the IBEM website (http:// campus.hesge.ch/ibem/amphibiens.asp).

Amphibians are a flagship group, often with a central importance for managers. As there is a low number of species, this is the only group where an exhaustive inventory (or nearly so) is possible. Such exhaustive inventory is particularly important for detection of rare species (also often threatened). This is, for example, the case in Switzerland where the gathered species list is forwarded to the national managers of the Swiss Amphibian breading sites (the KARCH, Swiss Amphibian and Reptile Conservation Programme), even though this species list is not useful for the IBEM index.

\section{Environmental variables}

Six environmental variables are measured for the IBEM-Index assessment (see next section): pond surface area $\left(\mathrm{m}^{2}\right)$, mean depth $(\mathrm{cm})$, shoreline index, pond shade (4 classes), percentage of woodland in a $50 \mathrm{~m}$ radius surrounding the pond, and altitude (m.a.s.l.). Methods are summarized in Table 2.

\section{METHOD FOR ASSESSING BIOLOGICAL QUALITY}

The IBEM assessment follows the methodology presented in the Water Framework Directive, and is based on the calculation of the ratio between true taxonomic richness $\left(S_{\text {true }}\right)$ and reference-based predicted richness $\left(S_{\text {ref }}\right)$. This score is translated into one of five quality classes for each pond: bad (0 to 0.2$)$, poor ( $>0.2$ to 0.4$)$, moderate $(>0.4$ to 0.6 ), good ( $>0.6$ to 0.8 ), and high ( $>0.8$ to $1)$. Each of the five taxonomic groups is assessed separately and the overall biological quality of any given pond (i.e. the IBEM-Index) is calculated by the average of the five ratios.

\section{True taxonomic richness $\left(S_{\text {true }}\right)$}

To compensate for the bias of a non-exhaustive sampling, observed taxonomic richness $\left(S_{\text {obs }}\right)$ is transformed into true taxonomic richness $\left(S_{\text {true }}\right)$ by a statistical estimator (Jackknife-1, Burnham \& Overton, 1979). $S_{\text {true }}$ is calculated for aquatic vegetation, Gastropoda, Coleoptera and Odonata either with specific software (for example EstimateS (Colwell, 2005)) or by means of our downloadable Microsoft EXCEL file ("calcul_richesse_Strue"), available at http://campus.hesge.ch/ibem/calcul.asp. The sampling of amphibian species is considered to be exhaustive (or nearly so); therefore the observed Amphibian richness equals $S_{\text {true }}$.

Table 2. Methods to measure the 6 environmental variables used for the assessment of a given pond by the IBEM-Index. Métodos de medida de las 6 variables medioambientales utilizadas para la valoración de una charca con el índice IBEM.

\begin{tabular}{lcl}
\hline \multicolumn{1}{c}{ Variables } & Units & \multicolumn{1}{c}{ Methods } \\
\hline $\begin{array}{l}\text { Pond surface area } \\
\text { Mean depth }\end{array}$ & $\begin{array}{l}\mathrm{m}^{2} \\
\mathrm{~cm}\end{array}$ & $\begin{array}{l}\text { Calculated using GIS, aerial photography or graph paper } \\
\text { Mean of the depths recorded in each vegetation square } \text { plot }^{1} \text { using a ruler or a handheld }_{\text {depth sounder }}\end{array}$ \\
$\begin{array}{l}\text { Shoreline index D } \\
\text { Pond shade }\end{array}$ & Class & $\begin{array}{l}\text { Vertical projection of the shadow of woody vegetation expressed in four classes: } \\
(1) 0 \%,(2)>0-5 \%,(3)>5-25 \%,(4)>25-100 \%\end{array}$ \\
Woodland (within $50 \mathrm{~m})$ & $\%$ & $\begin{array}{l}\text { Forest coverage in a radius of } 50 \mathrm{~m} \text { around the pond } \\
\text { Altitude }\end{array}$ \\
\hline
\end{tabular}

\footnotetext{
${ }^{1}$ If the pond is deeper than $3 \mathrm{~m}$, additional depth measurements must be carried out.
} 


\section{Predicted taxonomic richness $\left(S_{\text {ref }}\right)$}

The predicted taxonomic richness for reference conditions $\left(S_{\text {ref }}\right)$ is calculated for each taxonomic group using GAM models, based on a subset of 12 predicting variables (see Angelibert $e t$ al., 2009 for details). Six of these variables (trophic state, transparency, conductivity, percentage of floating-leaved and submerged vegetation, and fish presence) potentially describe pond degradation; they are therefore used to model reference conditions for each site. Indeed, the reference condition of a taxonomic group of a given pond is simulated by setting these 6 indicators of degradation to their "non-degraded" value, i.e. allowing the highest possible taxonomic richness. The other 6 predictors (surface, mean depth, shoreline development, pond shading, percentage of woodland in a $50 \mathrm{~m}$ radius, and altitude) are not sensitive to pond degradation and are therefore set to the field-measured values. A downloadable tool calculates $S_{\text {ref }}$ automatically (see next section).

\section{Calculating the IBEM-Index}

The IBEM-Index is calculated by a user-friendly tool, either directly online on the IBEM website (http://campus.hesge.ch/ibem/calcul_de_l_indice/ initialisation.asp) or by means of a downloadable Microsoft EXCEL file ("calcul_IBEM_v1.0"), available from the same website. The following elements are required to process the index: (i) true genus richness $\left(S_{\text {true }}\right)$ of aquatic vegetation, Gastropoda, Coleoptera and Odonata, (ii) observed species richness of Amphibia, (iii) 6 field-measured environmental variables. The user-friendly tool produces the predicted richness for each taxonomic group $\left(S_{\text {ref }}\right)$, calculates the ratio $S_{\text {true }} / S_{\text {ref }}$ and finally computes the IBEM-Index (see example in Fig. 6).

\section{APPLIED EXAMPLES}

As a demonstration, two ponds were assessed by the IBEM-Index and the whole process described

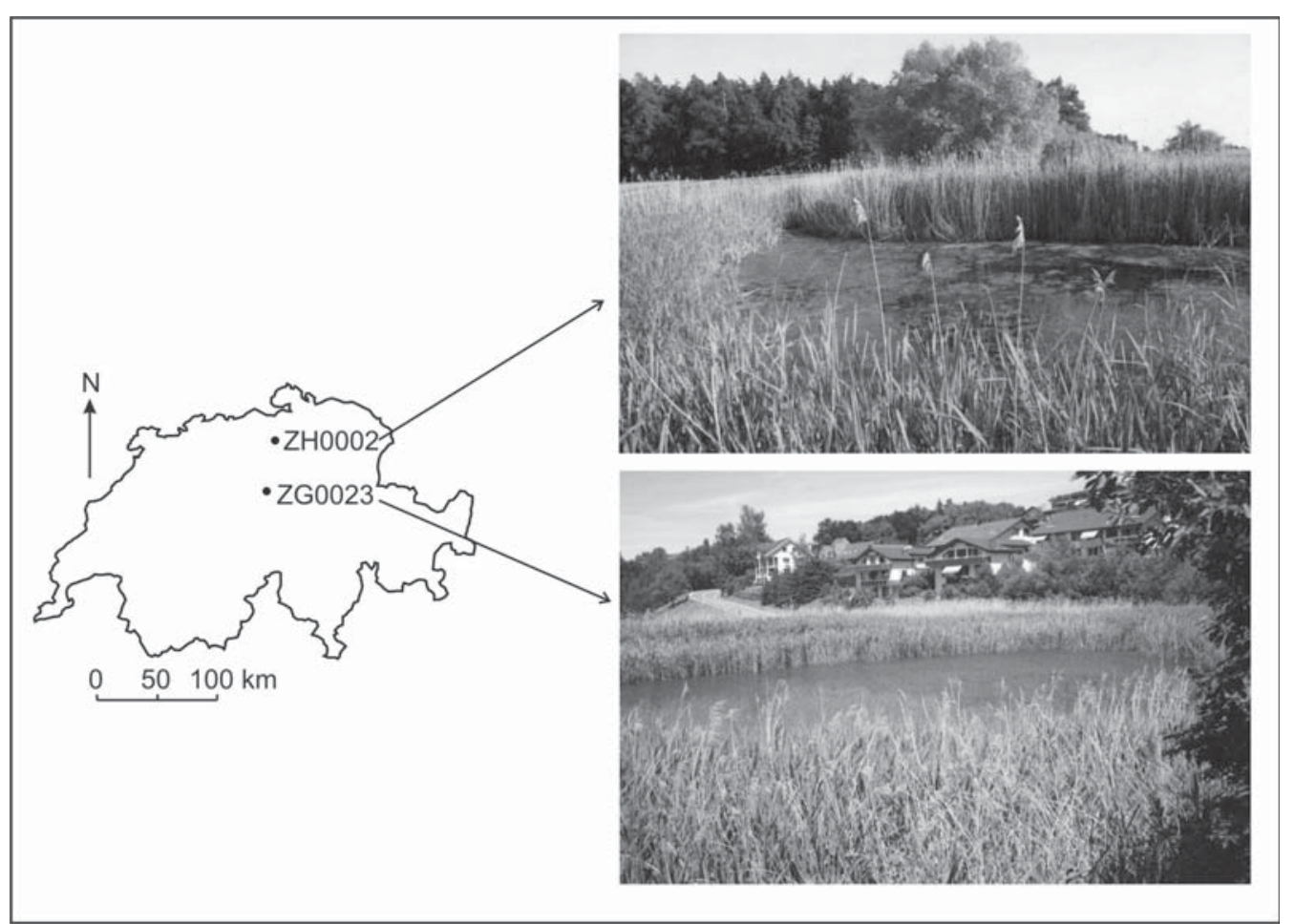

Figure 3. Geographical location of the ponds ZH0002 and ZG0023 in Switzerland. Localización geográfica de las charcas ZH0002 y ZG0023 en Suiza. 
Table 3. Values of the six environmental variables measured in the two ponds (ZH0002 and ZG0023) and required for the IBEM assessment. Valores de las seis variables ambientales requeridas para el índice IBEM, en dos charcas (ZHOOO2 y ZG0023).

\begin{tabular}{lcc}
\hline Variables & \multicolumn{2}{c}{ Ponds } \\
\cline { 2 - 3 } & ZH0002 & ZG0023 \\
Altitude (m a.s.l.) & 435 & 720 \\
Surface area (m $\left.{ }^{2}\right)$ & 640 & 1608 \\
Mean depth (cm) & 107 & 108 \\
Forested surrounding (\%) & 0 & 8 \\
Shoreline development & 1.29 & 1.22 \\
Shade (\% of the pond shaded) & 1 & 1 \\
\hline
\end{tabular}

here. The two ponds, ZH0002 and ZG0023, are located in lowland Switzerland (Fig. 3). These ponds are located in Adlikon (canton of Zurich) and Menzingen (canton of Zoug), respectively. Both waterbodies are relatively small $\left(640 \mathrm{~m}^{2}\right.$ for ZH0002 and $1608 \mathrm{~m}^{2}$ for ZG0023). Other physical pond characteristics are presented in Table 3 .

\section{Sampling}

According to the pond surface area and using the mathematical formula presented in the method section, aquatic plants were sampled in 16 and 25 square plots in ZH0002 and ZG0023, respectively. These square plots were equally distributed along transects (Fig. 4).

The mathematical formula presented in the method section was used to calculate the number of samples needed to survey for Gastropoda and Coleoptera: 7 and 10 samples in ZH0002 and ZG0023, respectively. The samples were stratified across the dominant mesohabitats (two mesohabitats in ZH0002 and 3 in ZG0023) (Fig. 5). Two thirds of the samples (5 and 7 respectively) were distributed along the shoreline aquatic habitats. The other third was distributed between the shoreline (excluding the shoreline itself) to a depth of $2 \mathrm{~m}$.

Adult Odonata were sampled in 3 plots distributed along the shoreline (Fig. 5). As these two ponds have a shoreline length $<270 \mathrm{~m}$ (e.g. $116 \mathrm{~m}$ and $124 \mathrm{~m}$ for ZH0002 and ZG0023 respectively), they were sampled along more than a third of the shoreline.

Amphibian species were recorded as described in the methods section.

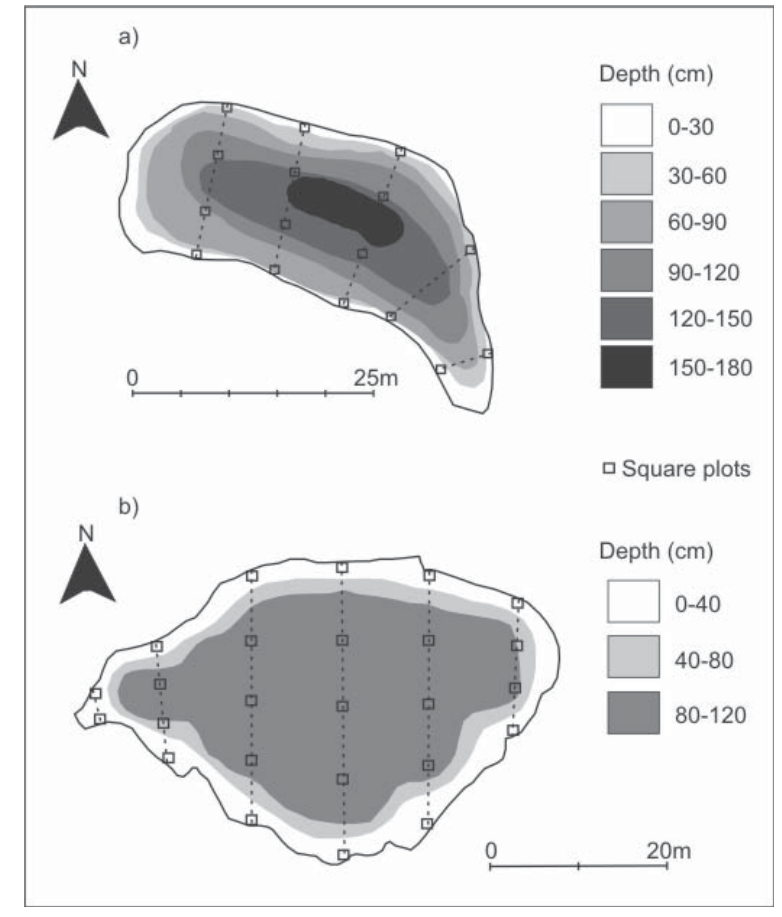

Figure 4. Distribution of square vegetation sampling plots along transects in the two ponds ZH0002 (a) and ZG0023 (b). Distribución de los cuadrados de muestreo de la vegetación acuática a lo largo de transectos en las dos charcas ZHOOO2 (a) y ZG0023 (b).

The six environmental variables required for the assessment by the IBEM-Index were also recorded (Table 3).

\section{Calculation of the IBEM-Index}

The observed taxonomic richness $\left(S_{\text {obs }}\right)$ was transformed into true taxonomic richness $\left(S_{\text {true }}\right)$

Table 4. Values of the observed taxonomic richness $\left(\mathrm{S}_{\text {obs }}\right)$ and true taxonomic richness $\left(\mathrm{S}_{\text {true }}\right)$ for the two ponds $\mathrm{ZH0002}$ and ZG0023. V: aquatic vegetation, G: Gastropoda, C: Coleoptera, O: Odonata, A: Amphibia. Valores de la riqueza taxonómica observada $\left(S_{\text {obs }}\right)$ y de la riqueza taxonómica real $\left(S_{\text {true }}\right)$ para las dos charcas ZH0002 y ZG0023. V: vegetacion acuatica, G: gasterópodos, C: coleópteros, O: odonatos, A: anfibios.

\begin{tabular}{llllccc}
\hline Ponds & & \multicolumn{5}{c}{ Taxonomic group } \\
\cline { 3 - 7 } & & $\mathrm{V}$ & $\mathrm{G}$ & $\mathrm{C}$ & $\mathrm{O}$ & $\mathrm{A}$ \\
\hline \multirow{2}{*}{ ZH0002 } & $S_{\text {obs }}$ & 10 & 7 & 8 & 10 & 5 \\
& $S_{\text {true }}$ & 11 & 7.9 & 12.3 & 12 & 5 \\
ZG0023 & $S_{\text {obs }}$ & 3 & 0 & 3 & 8 & 2 \\
& $S_{\text {true }}$ & 4 & 0 & 5.8 & 8 & 2 \\
\hline
\end{tabular}




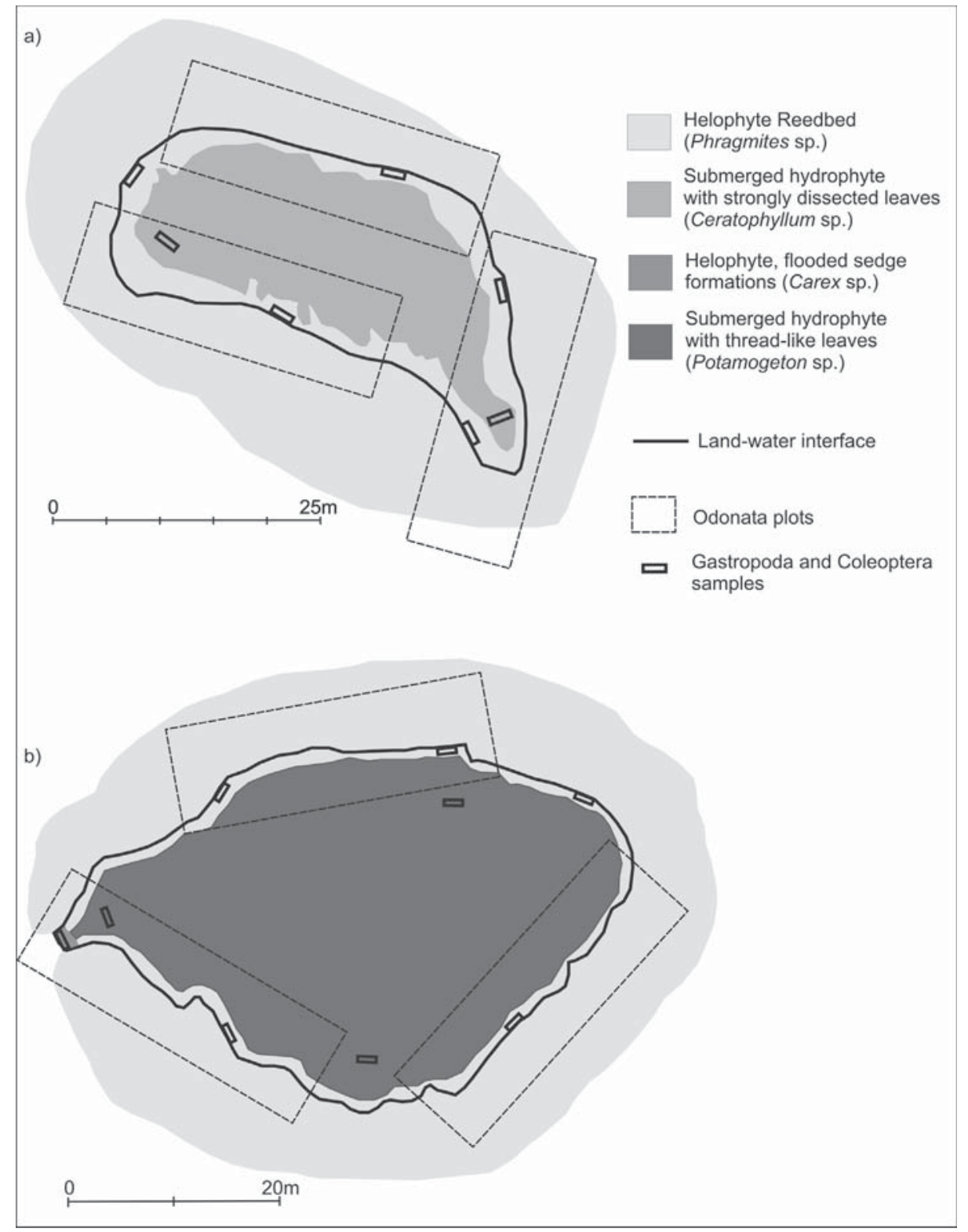

Figure 5. Example of distribution of the sweep-net samples for Gastropoda and Coleoptera and plots for adult Odonata in the two ponds ZH0002 (a) and ZG0023 (b). Ejemplo de distribución de las puntos de muestreo con redes de mano para gasterópodos y coleópteros y de las bandas de muestreo para odonatos adultos en las dos charcas ZH0002 (a) y ZG0023 (b).

by the statistical estimator Jackknife-1 (Burnham \& Overton, 1979) (Table 4). These values of true richness varied between 5 (Amphibians) and 12.3 (Coleoptera) for pond ZH0002, and between 0 (Gastropoda) and 8 (Odonata) for pond ZG0023. A list of the taxa recorded in both ponds is given in Appendix 1.
To calculate the IBEM-Index, we used the Microsoft EXCEL file "calcul_IBEM_v1.0" (Fig. 6). The user entered values in the grey cells (six environmental variables, five observed richness), and the results were automatically produced (Fig. 6, cells Ratio and Quality class). Note that the five taxonomic groups had to be used for a reliable 
assessment with the IBEM-Index. However, the user can exclude one or more groups (Fig. 6, cells
Group retained yes/no) in order to get a rough estimate of the biodiversity value of a pond.

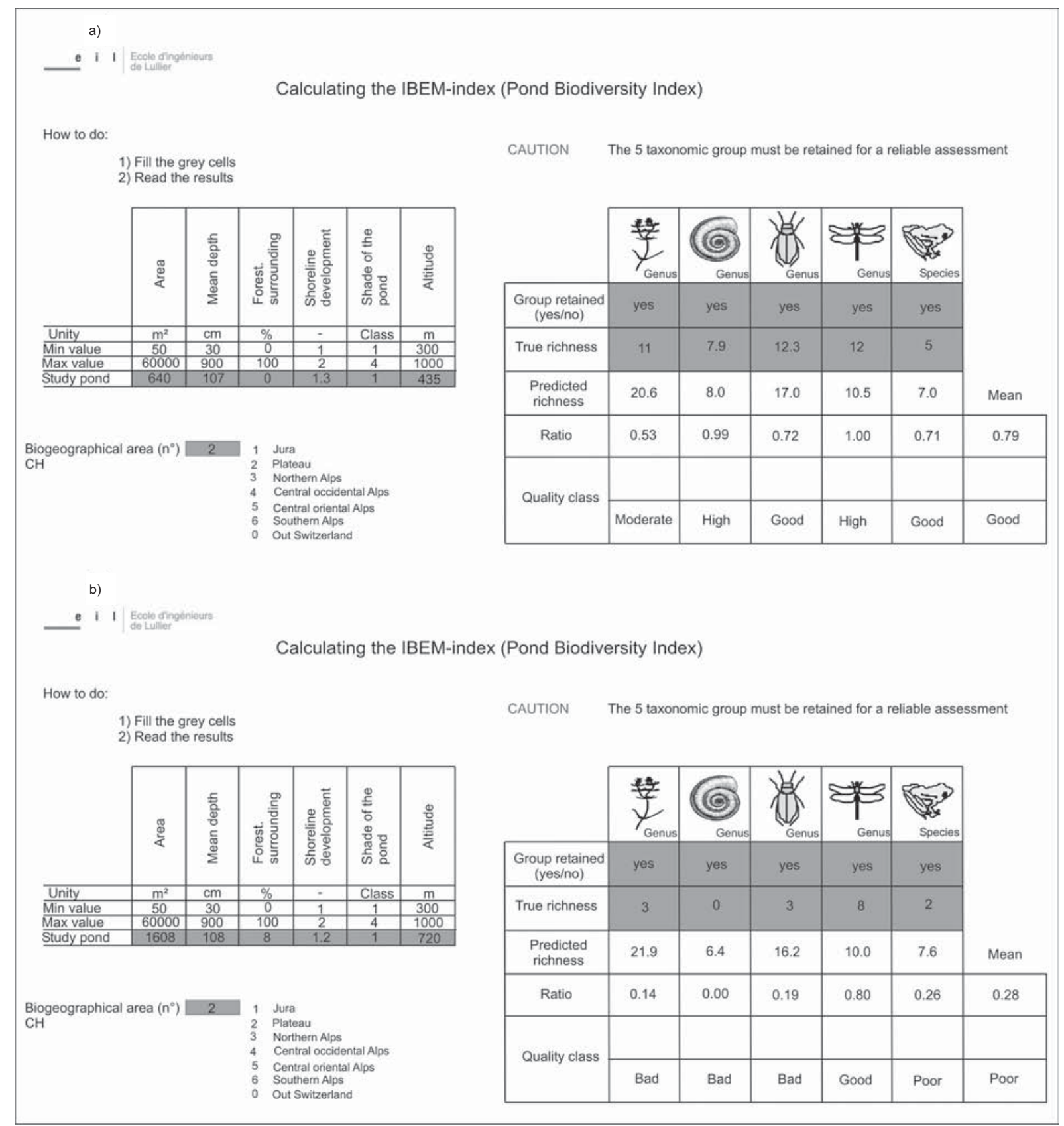

Figure 6. Calculation of the IBEM-Index for the two ponds ZH0002 (a) and ZG0023 (b) using the EXCEL file "calcul_IBEM_v1.0" (available in French and translated into English for this example) downloadable at http://campus.hesge.ch/ibem. This calculation can also be done online at: http://campus.hesge.ch/ibem/calcul_de_l_indice/initialisation.asp. Calculo del índice IBEM para las dos charcas ZH0002 (a) y ZG0023 (b) usando el archivo de EXCEL "calcul_IBEM_v1.0” (disponible en francés y traducido a inglés para este ejemplo) se puede descargar en http://campus.hesge.ch/ibem. Este cálculo puede realizarse también en la siguiente página de Internet: http://campus.hesge.ch/ibem/calcul_de_l_indice/initialisation.asp. 
ZH0002 has a good overall biological quality (Fig. 6a, IBEM-index = 0.79). In this pond, there was a high diversity of Odonata and Gastropoda, but aquatic vegetation was moderately diverse.

ZG0023 has a poor overall biological quality (Fig. 6b, IBEM-Index $=0.28$ ) mainly due to the poor aquatic vegetation, Gastropoda and Coleoptera diversity.

\section{DISCUSSION}

The IBEM-Index is a rapid assessment method which gives an indication of the value of a pond for biodiversity based on the number of taxa. It enables the identification of taxon-rich pond ecosystems, a task required by the 1992 Convention on Biodiversity. The IBEM method can be used in Switzerland for rapid biodiversity assessment, for example in regional surveys or for site monitoring. It is a reliable indicator of site quality, adapted for the assessment or monitoring of ponds belonging to natural sites of national importance (national inventory of marshes, moorlands, river backwaters, amphibian breeding sites). Besides producing the IBEM-Index, the datasets collected by the IBEM sampling method can later be used to study patterns of taxon richness and similarity between sites. Overall, the IBEM-Index is one of the tools available for nature conservation. For strictly species-related conservation issues, other tools which are also part of the "nature conservation toolbox" should be used, for example exhaustive inventories or red lists. Each tool has its specific objective and should be used appropriately.

As biodiversity is generally recognized as a good indicator of global ecological quality, the IBEM-Index can also be used to investigate the question of ecosystem quality, a central objective of the WFD. For example, the IBEM-Index was calculated for 63 Swiss lowland ponds, revealing a high proportion of ponds with poor or moderate biological quality (49\%, Fig. 7). Good quality was assigned to $38 \%$ of the ponds, and only $13 \%$ achieved the High quality class, and none of the assessed ponds were ranked in the lower quality class (i.e. Bad). This highlights that

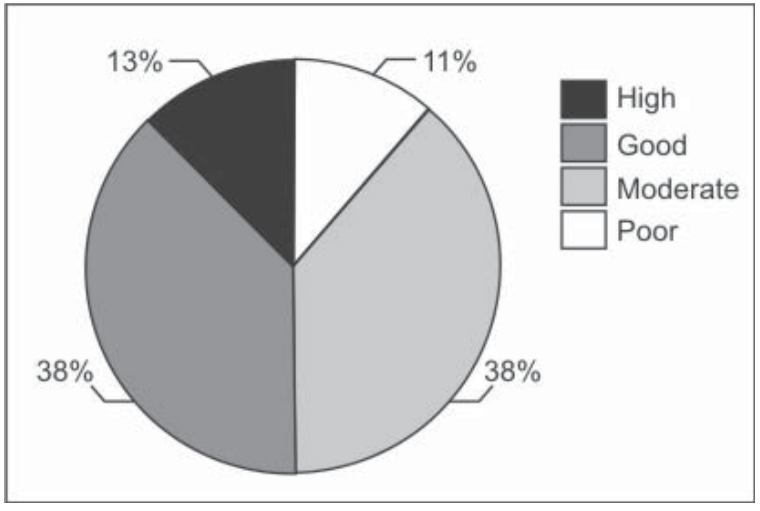

Figure 7. Biological quality of Swiss lowland ponds $(n=63)$, evaluated by the IBEM-Index. Estado ecológico de las charcas suizas de baja altitud $(\mathrm{n}=63)$ evaluadas mediante el índice IBEM.

about one pond out of two is actually degraded in terms of biodiversity, and this is likely to reflect global ecological quality. In the UK, the Countryside Survey 2007 shows that only $8 \%$ of ponds are currently in good condition and that the biological quality of lowland ponds decreased between 1996 and 2007 (Carey et al., 2008). The main objective of the WFD is to restore the quality of all waterbodies in Europe by 2015. However, in all European countries the implementation of the directive covers only waterbodies with a surface area greater than 50 ha, therefore excluding ponds. Despite this, some European regions are also applying WFD-type evaluation and monitoring programmes to ponds (for example some Spanish states e.g. Catalonia, Aragon). If Switzerland followed the WFD for small waterbodies, according to our results half of Swiss lowland ponds would have to be restored to good quality. Although this is not realistic because of the limited funding available for nature conservation and water quality management, our assessment shows that it is crucial to raise awareness of the importance of the conservation of ponds in Switzerland. Currently, ponds are mainly seen as a habitat for flagship species on the Red List. In the future, they should also be considered as an important element of a global landscape where all freshwater systems should have good ecological quality. Moreover, the consideration of the whole pond network is also very important at 
the regional scale. Although the IBEM-Index will not give a quality value to a regional richness, the taxa list gathered through the IBEM sampling can be useful to address the question of the pond network richness. For global ecological quality assessments, the IBEM-Index can be combined with metrics recently developed specifically for the assessment of the ecological quality of ponds in Switzerland (see Menetrey et al., 2005, 2008; Sager \& Lachavanne, submitted).

The IBEM-Index is valid in Switzerland and the close border regions of neighbour countries (i.e. with a $100 \mathrm{~km}$-wide belt). In others European regions, the sampling strategy and methodology can nevertheless be used directly. Conversely, the assessment of the biological quality (i.e. the calculation of the IBEM-Index) has to be adapted for each region: a reference condition must be assessed for each pond. The assessment of this reference value (i.e. for good ecological condition) can be done in four different ways (as specified in the WFD): i) using historical data (from a few years ago to paleoecological data) on similar ecosystems (same surface area, depth, altitude, shoreline) relatively naturals (i.e. unimpacted by human activities) at the time of sampling; ii) using current data on similar ecosystems, relatively naturals and located in the same region; iii) by consulting taxonomic experts to define the reference value of richness or iv) through prediction (i.e. using mathematical model of the relationship between diversity and the driving variables).

\section{ACKNOWLEDGEMENTS}

The IBEM-Index was developed with support from: Groupe d'Etude et de Gestion de la Grande-Cariçaie (GEG), Fondation des Grangettes, Musée Cantonal de Zoologie de Lausanne, Swiss Amphibian and Reptile Conservation Programme (KARCH), University of GenevaLaboratoire d'Ecologie et Biologie Aquatique (LEBA), Laboratoire des technologies de l'Information (Haute Ecole de Gestion de Genève), Consulting offices AMaibach Sàrl, Aquabug, Aquarius, GREN, and Natura.
The study of the Swiss ponds, which made the development of the IBEM-index possible, was supported by many partners: Swiss Federal Office for the Environment (FOEN), Cantons of Geneva, Jura, Vaud and Lucerne, Research commission of the Swiss National Park and HES-SO // University of Applied Sciences Western Switzerland (RCSO RealTech). Moreover we are grateful for the data provided by the Swiss Biological Records Center (CSCF) and the Swiss Floristic Database (CRSF).

Many thanks to the following persons for their various contributions: Céline Antoine, Dominique Auderset Joye, Diana Cambin, Gilles Carron, Emmanuel Castella, Jessica Castella, Michaël de la Harpe, Raphaelle Juge, Jean-Bernard Lachavanne, Anthony Lehmann, Simon Lézat, Nathalie Menetrey, Jane O'Rourke, Patrice Prunier, Corinne Pulfer, Nathalie Rimann, Mirko Saam, Lionel Sager, Emilie Sandoz.

\section{REFERENCES}

ANGELIBERT, S., N. INDERMUEHLE, D. LUCHIER, B. OERTLI \& J. PERFETTA. 2006. Where hides the aquatic biodiversity in the Canton of Geneva (Switzerland)? Arch. Sci., 59: 225-234.

ANGELIBERT, S., V. ROSSET, N. INDERMUEHLE \& B. OERTLI. 2010. The Pond Biodiversity Index "IBEM": a new tool for the rapid assessment of biodiversity in ponds from Switzerland. Part 1. Index development. Limnetica, 29: 93-104.

AUDERSET JOYE, D., B. OERTLI, R. JUGE \& J. B. LACHAVANNE. 2004. Evaluation écologique des étangs du Bois de Jussy. Département de l'Intérieur, de l'Agriculture et de l'Environnement du Canton de Genève (Service des forêts, de la protection de la nature et du paysage). University of Geneva, Geneva. 24 pp + appendix.

BIGGS, J., P. WILLIAMS, M. WHITFIELD, G. FOX, P. NICOLET \& S. HOWARD. 2000. A new biological method for assessing the ecological quality of lentic waterbodies. In: L'eau, de la cellule au paysage. Wicherek S. (ed.): 235-250. Elsevier, Paris, France.

BOIX, D., S. GASCON, J. SALA, M. MARTINOY, J. GIFRE \& X. D. QUINTANA. 2005. A new index of water quality assessment in Mediterranean 
wetlands based on crustacean and insect assemblages: the case of Catalunya (NE Iberian peninsula). Aquatic Conserv: Mar. Freshw. Ecosyst., 15: 635651.

BURNHAM, K. P. \& W. S. OVERTON. 1979. Robust estimation of population size when capture probabilities vary among animals. Ecology, 60: 927-936.

CAREY, P. D., S. WALLIS, P. M. CHAMBERLAIN, A. COOPER, B. A. EMMETT, L. C. MASKELL, T. McCANN, J. MURPHY, L. R. NORTON, B. REYNOLDS, W. A. SCOTT, I. C. SMART \& J. M. ULLYETT. 2008. Countryside Survey: UK Results from 2007. Centre for Ecology \& Hydrobiology. Lancaster. 105 pp. (available at http://www.countrysidesurvey.org.uk).

CHOVANEC, A., J. WARINGER, M. STARIF, W. GRAF, W. RECKENDORFER, A. WARINGERLÖSCHENKOHL, H. WAIDBACHER \& H. SCHULTZ. 2005. The Floodplain Index - a new approach for assessing the ecological status of river/floodplain-systems according to the EU Water Framework Directive. Arch. Hydrobiol. Suppl., 155: 169-185.

COLWELL, R. K. 2005. EstimateS: Statistical estimation of species richness and shared species from samples. Version 7.5. User's Guide and application published at: http://purl.oclc.org/estimates.

CORDOBA-AGUILAR, A. (ed.). 2008. DragonfliesDamselflies: Model Organisms for Ecological and Evolutionary Research. Oxford: Oxford University Press. Oxford, UK. 304 pp.

LANDOLT, E. 1977. Ökologische Zeigerwerte zur Schweizer Flora. Veröffentl. Geobot. Inst. ETH, Stift. Rübel, 64: 1-208.

MENETREY, N., L. SAGER, B. OERTLI \& J. B. LACHAVANNE. 2005. Looking for metrics to assess the trophic state of ponds. Macroinvertebrates and amphibians. Aquatic Conserv: Mar. Freshw. Ecosyst., 15: 653-664.

MENETREY N., B. OERTLI, M. SARTORI, A.
WAGNER \& J. B. LACHAVANNE. 2008. Eutrophication: are mayflies (Ephemeroptera) good bioindicators for ponds? Hydrobiologia, 597: 125135.

NICOLET, P., J. BIGGS, G. FOX, M. J. HODSON, C. REYNOLDS, M. WHITFIELD \& P. WILLIAMS. 2004. The wetland plant and macroinvertebrate assemblages of temporary ponds in England and Wales. Biol. Conserv., 120: 261-278.

OERTLI, B. 2008. Dragonflies in the assessment and the monitoring of aquatic habitats. In: DragonfliesDamselflies: Model Organisms for Ecological and Evolutionary Research. Cordoba-Aguilar A. (ed.): 79-95. Oxford University Press, Oxford, UK.

OERTLI, B., D. AUDERSET JOYE, N. INDERMUEHLE, R. JUGE \& J. B. LACHAVANNE. 2004. First European Pond Workshop. Arch. Sci., 57: 69-72.

OERTLI, B., D. AUDERSET JOYE, E. CASTELLA, R. JUGE, A. LEHMANN \& J. B. LACHAVANNE. 2005. PLOCH: a standardized method for sampling and assessing the biodiversity in ponds. Aquatic Conserv: Mar. Freshw. Ecosyst., 15: 665679.

SAGER, L. \& J. B. LACHAVANNE. 2009. The MNIP: a Macrophyte based Nutrient Index for Ponds. Hydrobiologia, 643: 43-63.

SCHMIDT, B. 2004. Actualisation de la Liste Rouge des amphibiens 2002 - 2005, Directives pour le travail de terrain, Directives révisées pour 2004. KARCH. 8 pp.

SOLIMINI, A., M. BAZZANTI, A. RUGGIERO \& G. CARCHINI. 2008. Developing a multimetric index of ecological integrity based on macroinvertebrates of mountain ponds in central Italy. Hydrobiologia, 597: 109-123.

WILLIAMS, P., M. WHITFIELD, J. BIGGS, S. BRAY, G. FOX, P. NICOLET \& D. SEAR. 2004. Comparative biodiversity of rivers, streams, ditches and ponds in an agricultural landscape in Southern England. Biol. Conserv., 115: 329-341. 
Appendix 1. Taxa recorded in the two test ponds. +: presence. Lista de organismos encontrados en las dos charcas utilizadas de ejemplo. +: presencia.

\begin{tabular}{|c|c|c|c|}
\hline \multirow[t]{2}{*}{ Taxonomic group } & \multirow[t]{2}{*}{ Genus or species } & \multicolumn{2}{|c|}{ Ponds } \\
\hline & & ZH0002 & ZG0023 \\
\hline \multirow[t]{11}{*}{ Aquatic vegetation } & Alisma sp. & + & \\
\hline & Carex sp. & + & + \\
\hline & Ceratophyllum sp. & + & \\
\hline & Juncus sp. & + & \\
\hline & Lemna sp. & + & \\
\hline & Lycopus sp. & + & \\
\hline & Lythrum sp. & + & \\
\hline & Mentha sp. & + & \\
\hline & Phragmites sp. & + & + \\
\hline & Potamogeton sp. & & + \\
\hline & Typha sp. & + & \\
\hline \multirow[t]{7}{*}{ Gastropoda } & Ferrissia sp. & + & \\
\hline & Gyraulus sp. & + & \\
\hline & Hippeutis sp. & + & \\
\hline & Physella sp. & + & \\
\hline & Planorbarius sp. & + & \\
\hline & Planorbis sp. & + & \\
\hline & Radix sp. & + & \\
\hline \multirow[t]{11}{*}{ Coleoptera } & Agabus sp. & & + \\
\hline & Dytiscus sp. & & + \\
\hline & Enochrus sp. & + & \\
\hline & Haliplus sp. & + & \\
\hline & Helochares sp. & + & \\
\hline & Hydrophylus sp. & + & \\
\hline & Hydroporus sp. & + & \\
\hline & Hyphydrus sp. & + & \\
\hline & Ilybius sp. & & + \\
\hline & Noterus sp. & + & \\
\hline & Oulimnius sp. & + & \\
\hline \multirow[t]{11}{*}{ Odonata } & Aeshna sp. & + & + \\
\hline & Anax sp. & + & + \\
\hline & Coenagrion sp. & + & + \\
\hline & Cordulia sp. & + & \\
\hline & Enallagma sp. & + & + \\
\hline & Erythromma sp. & + & \\
\hline & Ischnura sp. & + & + \\
\hline & Libellula sp. & + & + \\
\hline & Pyrrhosoma sp. & & + \\
\hline & Sympecma sp. & + & \\
\hline & Sympetrum sp. & + & + \\
\hline \multirow{5}{*}{ Amphibia } & Bufo bufo & + & + \\
\hline & Hyla arborea & + & \\
\hline & Green frog complex (Rana esculenta and $R$. lessonae) & + & \\
\hline & Rana temporaria & + & + \\
\hline & Triturus alpestris & + & \\
\hline
\end{tabular}

